\title{
Democracia, Igualdade e Sujeito de Direitos ${ }^{1}$
}

\author{
Norman Roland Madarasz \\ Pontifícia Universidade Católica do Rio Grande do Sul, Porto Alegre, RS, Brasil.
}

Gostaria de agradecer o convite, particularmente agradecer ao meu colega do Programa de Pós-Graduação em Filosofia da PUCRS, o professor Nythamar de Oliveira, por ter sugerido que eu o substituísse, apesar de ser com pouca antecedência, na verdade. É um prazer e um desafio falar sobre estes temas: Direitos Humanos, Ética e Democracia. É um prazer, digamos, num sentido mais abrangente, particularmente neste momento em que internacionalmente podemos ver que estamos num período de questionamento das normas, das formas e da estrutura da democracia. Mas não deixa de ser um desafio, pois ao tentar ocupar uma perspectiva crítica sobre a democracia, temos que nos localizar perto da sua estrutura, nos colocar fora dela, ou pelo menos mostrar que somos capazes de fazê-lo, enquanto seres responsáveis. Não é nada simples nem seguro ocupar esta posição, mesmo se levamos uma caixa de ferramentas normativas, em que se encontram a ética e a filosofia de direitos humanos. Ao conhecer a história, devemos ficar prontos para surpresas.

No entanto, não precisamos tal distanciamento para constatar que no plano político internacional, demandas democráticas estão tomando formas em lugares que, antigamente, foram descartados. Estamos seguindo os movimentos que se iniciaram em 2011, não apenas no mundo árabe, mas também nos Estados Unidos e no Canadá. Um dos assuntos que gostaria de relatar para vocês, mas que guardarei para o fim da minha fala, é justamente o caráter da greve social que está acontecendo atualmente na província do Quebec, greve social disparada por uma greve de estudantes universitários e as associações que os representam. Aqui no Brasil, já que é difícil ter notícias do Canadá, muitas vezes, encontrei-me na tarefa complicada de defender que o Canadá realmente existe. Nas notícias, ouve-se falar de tempestades ou perturbações climáticas que parecem parar sempre na fronteira norte dos Estados Unidos, curiosamente 
nunca passando até os grandes centros do Canadá que, em muitos casos, nem se situam a mais de cem quilômetros da fronteira. Parte da minha função aqui no Brasil deve ser esta: confirmar que o Canadá existe. Parte desta confirmação envolve salientar também que no Canadá existe uma região, uma província, uma "nação" singular, o Quebec. De fato, ela existe, e quero explicar o quanto ela existe, como democracia e como campo de expressão comunitária de uma ética politizada (Madarasz, 2012).

Nesta expressão de um leve incômodo, não quero culpar apenas o Brasil. Devo relatar um caso de ignorância, justamente por esta falta de conhecimento sobre aquele país que parece, às vezes, não existir. Eu tenho que admitir que um dos grandes momentos de vergonha que eu pude testemunhar foi em 2001, quando aconteceu a grande reunião do Acordo de Livre Comércio das Américas, na cidade de Quebec. O jornal intelectual da elite québécois, Le Devoir, apresentou um suplemento sobre os "três grandes idiomas das Américas". Estes idiomas eram: francês, inglês e, vocês já estão adivinhando, espanhol. Entendo, então, que o Canadá não seja tão citado e reconhecido a partir do Brasil.
Enfim, o tema do Canadá será apenas um suplemento que eu tentarei encaixar na problemática que tem mais a ver realmente com a França e com a filosofia francesa contemporânea: a minha área de pesquisa, de preocupação e de paixão. Por meio desta rica expressão filosófica "mais que nacional", orientarei a análise sobre o que Marcel Gauchet denomina "l'observatoire francais", isto é, o observatório do terreno político francês.

$\mathrm{Eu}$ gostaria de apresentar brevemente a questão da ética, da democracia e dos direitos humanos vistos por uma perspectiva francesa, e acentuá-la a partir de outra. Apresentarei as grandes linhas das posições sobre a política e a questão do sujeito, pensadas filosoficamente por Alain Badiou e Jacques Rancière, dois mestres atuais da filosofia francesa.

Ao contrário da história recente da França, desde os anos 1980 até o período atual, identifica-se hoje uma transformação considerável no que diz respeito à viabilidade de conversar sobre modelos de governança diferentes da democracia. Isso justamente acontece simultaneamente aos movimentos “Occupy!" nos países ocidentais, que realmente foram despertados pela crise financeira internacional, isto é, o quase colapso do 
sistema financeiro e bancário estadunidense em 2008, e a mudança de paradigmas econômicos dos governos dos principais países liberais. Mudança, sim, porque a crise de repente tornou necessário um investimento enorme por diferentes Estados para salvar a economia, apesar de o neoliberalismo justamente pregar um recuo do Estado no que diz respeito a investir na sociedade e, mais especificamente, no mercado.

A grande mudança que acontece afeta justamente a questão dos Direitos Humanos e, por conseguinte, as ecologias natural e urbana. $\mathrm{Na}$ França, particularmente nos anos 1970, começam a se manifestar os Direitos Humanos como discurso que vem mudando as justificações por trás da intervenção da "metrópole" em países que antigamente existiam dentro do domínio colonial. A perda de importantes colônias, como a Indochina nos anos 1950 e a Argélia nos anos 1960, marca o período da descolonização, período que afetou outros países, tais como a Inglaterra, Portugal e os Estados Unidos. Após estas longas guerras de martírio nacional e genocídio colonial, a França foi confrontada ainda com vários movimentos autonomistas, como no Taiti e na Nova Caledônia. Ao mesmo tempo, começa a transformação do perfil da atuação da
França em países remotos. A França não deixará de intervir militarmente em países como o Chad (1983-84) e a Ruanda (1994), mesmo que a natureza da justificação se transforme. A mudança ocorre conforme a necessidade de comunicar à nação francesa, de modo mais transparente, o caráter da intervenção militar. No caso de Ruanda, investigações comissionadas tanto pelo Governo de Ruanda quanto pela Assembleia Nacional Francesa apontaram inúmeros erros envolvidos na missão francesa. Com isto, teria parado o genocídio cometido contra os Tutsis e o exército francês teria deixado fugir para, o então, Zaire vários assassinos Hutus. A mudança ocorre também devido aos interesses cruzados frente ao colapso da antiga Iugoslávia, iniciada já em 1992, uma guerra civil em que a França chefiou em vários momentos as ações dos Capacetes Azuis da Organização das Nações Unidas (ONU). A nova justificação de operações militares será doravante humanitária, num gesto de proteção aos direitos humanos.

No exposto até aqui, já dá para perceber que estão em foco dois tipos de intervenções, um estritamente militar e neocolonialista, e outro humanitário. Porém, esta separação desaparece assim que nos detemos em questionar de maneira 
mais escrupulosa a noção de interesse. Já que a questão militar não é o assunto de hoje, faremos uma asserção que deve também ser uma conclusão provisória, que procurarei instanciar nas análises de Badiou e Rancière: a França organiza uma economia militar industrial que precisa, mais que ocupar territórios alheios, exercitar-se neles. Tanto o uso do discurso dos Direitos Humanos como a proteção dos interesses democráticos franceses se equivalem nos dois tipos de operações militares. Ainda mais, este discurso pelo qual se justifica a realização de intervenções humanitárias se tornou, pouco a pouco, o modelo que justifica a atuação internacional dos Estados Unidos, especialmente quando desaparece o álibi para o combate, o que Henry Kissinger chamava de o "efeito dominó" do comunismo.

No caso dos Estados Unidos, após o período em que o Presidente Ronald Reagan enviava mercenários para aterrorizar os camponeses nas fronteiras da Nicarágua para, por assim dizer, impedir este pequeno país comunista de levar a revolução até o seu próprio território, começam as ações humanitárias. Bill Clinton emprestou-lhe o charme da sua inteligência tanto quanto de sua corpulência. A Iugoslávia entra numa guerra civil nos anos 1990, e o governo multiétnico, em nome da maioria muçulmana do estado secessionista da Bósnia Herzegovina, fez apelos desesperados para ajuda humanitária e militar contra a agressão serva. Entre 1995 e 1999, se inicia neste território uma série de ações militares com objetivos humanitários. Isso se intensifica no Afeganistão depois dos ataques de 11 de setembro de 2001, quando a defesa dos direitos das mulheres, entre outros, foi usada para justificar a intervenção da Administração de George W. Bush para derrubar o poder Talibã. Vale lembrar, justamente para começar a salientar as contradições envolvidas na alegada defesa dos direitos humanos, que a rede de sustentação do talibã envolvia o Paquistão, a Arábia Saudita, e os mujahidin antissoviéticos sob o comando de um certo Osama Bin Laden. Todos os mencionados nesta rede participavam até certa data do domínio de influência dos Estados Unidos na Ásia central.

Portanto, temos esta primeira constatação meramente histórica e descritiva, seguida por um questionamento. O debate sobre os direitos humanos surge na França, em meados dos anos 1970, no momento em que se presenciam vários regimes de terror ao redor do mundo: da 
Argentina até o Camboja. Porém, devido a uma voz cada vez mais expressiva do grupo de intelectuais em torno de Raymond Aron e François Furet, este debate se transforma em discurso que vem defendendo a política das democracias contra o denominado "totalitarismo" dos países comunistas da Europa oriental, da América latina, da África e da Ásia.

Os Direitos do Homem apresentam uma longa história na França. Da Declaração dos direitos do homem e do cidadão em 1789 passando pela criação da Liga dos direitos humanos na época do "Affaire Dreyfus" até a Declaração Universal de Direitos Humanos em 1948 e a Convenção Europeia de direitos humanos em 1960, parte da política nacional de sucessivos governos franceses é o reforço jurídico da proteção destes direitos, tanto nacional quanto internacionalmente. No primeiro momento, a crítica feita pelos governos e intelectuais franceses aos Estados de cometer abusos contra as suas populações, visa reforçar esta orientação. Por isso, é surpreendente encontrar o engajamento militante de Michel Foucault, neste momento. Didier Eribon falou que Foucault ainda manteve uma amizade importante com Louis Althusser enquanto lançava as suas condenações ao marxismo nos anos 1970, mesmo que Eribon também salientasse que a amizade entre os dois era mais epistemológica do que política (Eribon, 1994: pp. 192-204).

Contudo, aquilo que vem à tona nos anos 1980 é de outra natureza. Por um lado, faz parte do teor geral da política internacional da época, a rejeição uniforme às tentativas de impor um igualitarismo de fato por causa dos crimes proporcionados por estes Estados. Por outro, quando aplicado para justificar intervenções militares em outros países, o discurso dos direitos humanos vem cortando o debate público em torna dos interesses mais extensos dos grandes poderes ao defender os civis em zonas de guerra. A conclusão tomada por boa parte da intelligentsia francesa era de que os projetos de igualitarismo socioeconômico deveriam ser condenados não apenas pelos desastres políticos que haviam cometido, mas, especialmente, por princípios filosóficos e éticos.

As análises que acabei de expor são representativas dos trabalhos de Badiou e Rancière no fim dos anos 1980; análises estas, que seja dito, opuseram-se às diatribes de Foucault contra o marxismo. Badiou expôs essa análise para o grande público em 1993, no seu livro: Ética. Um Ensaio sobre a consciência do mal.

De acordo com Badiou (1993/1995): 
A ética é (...) concebida ao mesmo tempo como capacidade a priori de distinguir o Mal, (porque, segundo o uso moderno da ética, o Mal - ou o negativo - vem primeiro: supõe-se um consenso sobre o que é bárbaro) e como princípio último do julgamento, particularmente do julgamento político: é exatamente o que intervém de maneira visível contra um Mal identificável a priori. O próprio direito é inicialmente o direito "contra" o Mal. O "Estado de direito" é requisitado porque somente ele autoriza um espaço de identificação do Mal (a "liberdade de opinião", na visão ética, é de início liberdade de designar o Mal) e fornece os meios para arbitrar quando as coisas não estão claras (aparato de prevenções judiciárias) (p. 23).

O contexto de discussão aqui é o da desqualificação e do descrédito em que caiu o comunismo ou os projetos de emancipação universal nos anos 1970, e o discurso que surgiu para reforçar a primazia moral do liberalismo democrático. Badiou entra num debate com o pensamento que se tornou la pensée unique na França, isto é, o pensamento único. Ao longo de duas décadas, o pensamento único determinou que toda tentativa de realizar o bem comum ou a verdade comum na ordem da política e da economia está destinado a acabar em desastre, isto é, que a política é tudo menos o lugar em que se cria a verdade, a não ser de forma que evidencia certo fanatismo. Conforme a reorientação da ética como aquilo que justifica a política e, não o contrário, o pensamento único considera que tais projetos, que encaminham a sociedade em rumo ao conflito aberto, são não apenas "irresponsáveis", mas encarnam o mal. Este discurso que se opõe às possibilidades de criar uma sociedade ética e justa porque é igual de fato, alicerçada no ideal do bem como ideia reguladora, tem quatro pressupostos que Badiou destaca:

$1^{\circ}$. Supõe-se um sujeito humano geral tal que o que lhe sucede de mau seja identificado universalmente (embora esta universalidade, seja com frequência chamada por um nome absolutamente paradoxal, “opinião pública”), de modo que este sujeito é ao mesmo tempo um sujeito passivo, ou patético, ou reflexivo (aquele que sofre); e um sujeito de julgamento, ou ativo, ou determinante: aquele que, identificando o sofrimento, sabe que é preciso fazê-lo cessar por todos os meios disponíveis.

$2^{\circ}$. A política é subordinada à ética, do único ponto de vista que verdadeiramente importa nesta visão das coisas, o julgamento compassivo e indignado do expectador das circunstâncias. 
$3^{\circ}$. O Mal é aquilo a partir do que se dispõe o Bem e não o inverso.

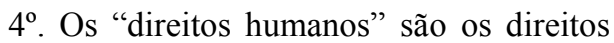
ao não-Mal: não ser ofendido, não ser maltratado em sua vida (horror à morte e à execução), em seu corpo (horror à tortura, às sevícias e à fome), nem em sua identidade cultural (horror à humilhação das mulheres, das minorias, etc. (Badiou, 1993/1995, p. 23-24)

Reconhece-se nesta análise como Badiou enxerga a lenta substituição de projetos políticos por uma doutrina da ética, ou seja, um discurso ético que vem dispersando a ética conceitual focada em todos. A política sendo vista justamente como se estivesse levando, lidando, ou conduzindo a vários desastres quando mexe com a estrutura democrática ou parlamentar do Estado de Direito. Com isto, a questão dos Direitos Humanos foi utilizada como discurso para justificar as intervenções do Estado francês em vários países da África, e forneceu aos Estados Unidos esta justificação de intervenção. Contudo, Badiou visa algo mais profundo. Ele visa levar a cabo o encerramento da reflexão igualitária, visando encerrar a expulsão do maior desafio ao pensamento político, supostamente, por motivo decorrente do igualitarismo. O objetivo é de se opor a esta conclusão sumária, formulada pela intelligentsia tecnocrática, numa narrativa parcial das lutas políticas do século. No âmbito da filosofia, esta tarefa subscreve à necessidade de se construir uma ontologia para fundamentar a justiça dos motivos por estas reivindicações prescritivas, mas orientando a finalidade do processo na ideia de igualitarismo de fato, o que implica submeter à avaliação de graus de liberdade a realização concreta de igualdades. A liberdade sem igualdade é uma traição da ética filosófica.

Praticamente ao mesmo tempo, em 1995, Jacques Rancière publica o seu livro, O Desentendimento, em que se propôs a criticar a estrutura democrática de governança, conceitualizada como a "Polícia". O motivo desta crítica radical é o princípio latente nas democracias liberais que um setor da sociedade ficará, por força maior, fora da "conta" administrativa e jurídica. A doutoranda Daniela Duarte Dias citou o número de encarcerados no país. Ela nos fez lembrar as pessoas que ainda não chegaram a ter direito realmente a se formar, participar, e ter uma voz na sociedade, cuja presença e sofrimento não deixam que a democracia representativa funcione de fato. Isto, considerando suas liberdades políticas tais como o voto obrigatório, suas bancadas em que lobbies 
e políticos são indistinguíveis cuja realidade é um etos de corporativismo. Ora, Daniela evocou o que Rancière designa como os “incontados". Da mesma forma, Rancière coloca em dúvida a coerência do discurso dos Direitos Humanos ao não dar conta desta situação. Lerei agora um comentário sobre os Direitos Humanos que terá vários pontos em comum com a posição de Badiou.

No livro O Desentendimento, Rancière explica que:

a transformação da cena democrática em cena humanitária pode ser ilustrada pela impossibilidade de um modo de enunciação. No início do movimento de maio de 68 na França, os manifestantes haviam definido uma forma de subjetivação resumida em uma frase: "somos todos judeus alemães". Essa frase ilustra bem o modo heterológico da subjetivação política: tomando ao pé da letra a frase estigmatizante do adversário, preocupado em despistar o intruso sobre o palco em que se contavam as classes e seus partidários, ela a invertia para convertê-la numa subjetivação aberta dos incontados, um nome sem confusão possível com qualquer grupo social real, com qualquer cômputo de identidade. É evidente que uma frase deste tipo seria hoje impronunciável, por duas razões. A primeira é que não é exata. Os que a pronunciavam não eram alemães e não eram, na sua maioria, judeus. Ora, todos os partidários do progresso como os da ordem admitiram desde então que só são legitimas as reivindicações de grupos reais que tomam pessoalmente a palavra para dizerem, eles mesmos, sua própria identidade. Ninguém doravante tem o direito de se dizer proletário, negro, judeu ou mulher se não o for, se não tiver essa qualidade nativa e sua experiência social. A única exceção a essa regra de autenticidade, é claro, é a "humanidade" cuja autenticidade consiste em ser sem palavra e cujos direitos estão nas mãos da polícia da comunidade internacional. E aí aparece a segunda razão: a frase é doravante impronunciável, porque é evidentemente indecente. A identidade "judeu alemão" hoje significa imediatamente a identidade da vítima do crime contra a humanidade, que ninguém poderia reivindicar sem profanação. Ela não é mais um nome disponível para a subjetivação política, mas um nome da vítima absoluta que suspende essa subjetivação. $\mathrm{O}$ sujeito do desentendimento tornou-se o nome do interdito. A era humanitária é aquela em que a ideia da vítima absoluta proíbe os jogos polêmicos da subjetivação do dano.

(Rancière, 1995/1996, p. 126)

Mesmo assim, esta subjetivação é precisamente aquela em nome da qual os poderes justificam a ingerência em territórios soberanos, reconhecidos na Carta da ONU. Nesta caracterização de 
uma "era humanitária", Rancière está aludindo especificamente ao mesmo momento de confusão no observatório francês nos anos 1970 e de suas repercussões diretas e indiretas na política internacional deste país. A confusão surgiu quando, após anos de militância, e em vários casos de organização subversiva clandestina, um grupo de líderes do mais radical dos movimentos de contestação, $\mathrm{La}$ Gauche prolétaire, orquestrou uma ruptura pública cuja dimensão midiática teve um forte impacto na ordem política francesa. Composto de vários filósofos sartrianos, a organização publicava o tratado La Cause de Peuple, que se tornou em 1973 o jornal Libération. $\mathrm{O}$ novo grupo fez um espetáculo midiático também pelas aparências dos principais porta-vozes. Ao se autodenominarem "novos filósofos", o grupo rompeu com a esquerda e focou sobre os conceitos de democracia e direitos humanos. Portanto, "nova filosofia" no contexto francês é um movimento que acontece em torno de 1976-77, composto de uma migração no espectro político de um grupo de jovens militantes, principalmente maoístas, que adotaram uma posição de liberalismo, democracia, defesa dos Direitos Humanos e uma condenação do comunismo como necessariamente "totalitário", por meio de uma associação da sua finalidade com a do nazismo. Em suma, havia migração de uma organização potencialmente subversiva para um clique de conselheiros do príncipe, ou no caso do presidente, e de futuros presidentes. Os novos filósofos salientarem os relatos de Alexander Soljenítsin, cuja obra O Arquipélago Gulag foi traduzida na França em meados dos anos 1970. Veio a rejeição do marxismoleninismo e do maoísmo pelos principais pensadores da esquerda, o que proporcionou a institucionalização do argumento segundo o qual o marxismoleninismo não foi nada mais do que uma forma do mal na ordem da política. A nova filosofia, identificada com pensadores como André Glucksmann e Bernard-Henri Lévy, são muito ativos ainda na imprensa francesa e, recentemente, no governo de Nicolas Sarkozy, cuja cumplicidade com os governos ditatoriais de M. Muammar alGaddafi na Líbia (caso de financiamento de campanha eleitoral) e Zine el-Abidine Ben Ali da Tunísia, amigo pessoal da antiga ministra da defesa Michele AlliotMarie.

Situados os detalhes históricos nesta etapa do observatório francês, Rancière continua ao explicar que 
o episódio que se chamou "nova filosofia" resume-se inteiramente nesta prescrição: o pensamento do massacre é o que marca de indignidade o pensamento e proíbe a política. O pensamento do irresgatável vem então servir de duplo ao realismo consensual: o litígio político é impossível por duas razões: porque suas violências são um entrave para o acordo racional das partes; e porque as facécias de suas encarnações polêmicas ultrajam as vítimas do dano absoluto. A política deve então ceder diante do massacre, o pensamento inclinar-se diante do impensável. (Rancière, 1995/1996, p.126-127)

No final, o teor do argumento evoca uma posição semelhante à posição de Badiou na medida em que temos esta crítica da política entendida como sendo uma política de invenção. Uma política de emancipação, uma tentativa de expandir o aspecto democrático do Estado francês e, em outros casos, estabelecer uma democracia em nome de princípios éticos do bem, da verdade e da justiça, mas, sobre o pano de fundo de uma igualdade de fato como função da distribuição comum e da projeção universal dos bens. Sem este horizonte de exigências, o liberalismo democrático se justifica como um sistema de governança superior, ou pelo menos, o menos mal. A ética, assim, justifica uma suspensão do trabalho na pesquisa política que vai no sentido de criações de formas de governança em oposição à doutrina humanitária que tomou posse do discurso universal dos Estados.

Esta situação vai sofrer uma mudança explosiva justamente com a eleição do governo de Nicolas Sarkozy. O que encontramos na França, na verdade, por trás do sistema democrático, tem um reforço da estrutura oligárquica do Estado francês. Cornelius Castoriadis, um pensador que se destacou numa linha liberal nos anos 1970, mas cujas origens políticas estão no trotskismo e na crítica da burocratização e da militarização do comunismo na União Soviética, manteve com firmeza esta crítica da democracia francesa, minada pelo controle oligárquico do Estado (Castoriadis, 1989). Ele defende que as sociedades liberais conseguiram implementar certo grau de autonomia, mas esta autonomia se realizou enquanto $\mathrm{o}$ Estado se manteve distante das demandas democráticas em vista de uma reforma mais abrangente.

Será esta a posição que Badiou e Rancière desenvolverão para denunciar a estrutura oligárquica deste Estado que não tem mais respostas a dar às demandas da sociedade. A taxa de desemprego se mantém estruturalmente alta, e a classe política finge ignorância ao não 
desconectar a questão da crise econômica e do desemprego de um discurso racista crescente nos anos 1990, sendo que o alto nível de desempregados está regularmente atribuído à presença de grandes números de imigrantes ao invés da organização dos modos de produção. Sabemos que a França, a Alemanha e outros países da Europa têm visto um crescimento de discursos racistas, particularmente, para confrontar as causas aparentes da crise. Isso vai intensificando a manifestação da oligarquia sobre a necessidade de manter a estrutura atual do Estado francês. Vai se transformar e se fazendo cada vez mais explícita e transparente ao ponto que chegamos ao governo de Nicolas Sarkozy em que a colaboração entre a classe política e a oligarquia industrial financeira será apresentada ao público como sendo o novo perfil, a nova face do Estado francês. Neste contexto, vários intelectuais, presentes na institucionalização do discurso humanitário, entrarão no governo de Nicolas Sarkozy.

Bernard Kouchner é um dos principais intelectuais que institucionalizou o discurso dos Direitos Humanos, antes de se tornar ministro dos assuntos estrangeiros do governo Sarkozy. A posição econômica do governo Sarkozy, porém, era uma posição neoliberal de recuo do Estado frente aos investimentos na sociedade, nas instituições e nos programas sociais. O que acontece a partir de 2008, entretanto, é o uso dos recursos públicos para salvar os bancos da crise que chega à Europa em 2009. Os canais pelos quais circulou o mar de resgates seguiram a infiltração pelo banco de investimento Goldman Sachs de várias agências do Estado federal. Com esta posição passiva diante da crise econômica, o discurso humanitário some do principal palco. A questão dos Direitos Humanos não parece ser mais um elemento chave da estrutura da democracia nestes países. O caso da ética aparece ainda pior: ainda surge a constatação da fraqueza da questão ética, ou seja, simplesmente não há força ética para tratar o mal social.

Esta suspensão do compromisso ético e da dedicação em proteger os direitos humanos é mexer com um componente que, Marcel Gauchet, trabalha na linha de Castoriadis, indica como sendo um dos pilares fundamentais da democracia (Gauchet, 2007). A submissão, de aparência natural, da ética às exigências da crise econômica, desvela as falhas na ordem e no caráter do princípio da democracia. Desta forma, os movimentos para repensar a estrutura de subjetivação política emancipada reencontraram, no 
nível das lutas e da formação coletivista, ao invés da política internacional, as possibilidades vivenciadas no passado, na história do comunismo.

A partir dos trechos citados dos livros "Ética", de Badiou, e "O Desentendimento", de Rancière, constataremos que a crítica dos Direitos humanos significa três coisas:

$1^{\circ}$. Aquilo que criticam em Badiou e Rancière não é o debate, nem as reivindicações populares pelo respeito dos direitos, nem tampouco a ação do Estado por meio do poder judiciário a proteger a população. Eles criticam a transformação do debate em discurso para justificar atos de violência de Estado, cujos motivos nunca são restritos à mera proteção dos civis. Em outras palavras, eles apontam para uma contradição estruturante na razão do Estado, no que diz respeito à defesa dos direitos dos indivíduos. Os Estados ainda se comunicam principalmente com outros Estados e com o setor empresarial. É uma relação que o liberalismo defende, nem sempre de maneira latente, no seu princípio de justiça. Por isso, o discurso se torna propício a ser refutado.

$2^{\circ}$. Tanto Badiou quanto Rancière fazem um levantamento do referencial crescente aos direitos humanos como ocorrendo num momento de enfraquecimento dos movimentos populares e de esquerda. O discurso dos direitos humanos aproveita para condenar, às vezes num objetivo a priori, o projeto de realizar um igualitarismo de fato, e não apenas de jure, na sociedade atual.

$3^{\text {o }}$. Os dois pensadores também rejeitam a base ética do discurso dos direitos humanos justamente por causa da sua arbitrariedade, o que se traduz em universalismo para alguns, ou num relativismo ocultado. A ética tem pertinência apenas quando estendida a todos no espaço social. Quando vem protegendo apenas os cidadãos com $\mathrm{o}$ poder executivo e midiático, e com o conhecimento da lei suficiente para ativar o judiciário, então se trata meramente de etos, qualquer que seja seu embasamento teórico. Um discurso ético transformado em etos e que se justifica como tendo uma extensão universal é nada menos que uma ideologia.

As diferenças entre Rancière e Badiou são numerosas. Quero me deter em apenas duas. A principal diferença entre esses autores é a recusa de Rancière em acreditar que uma emancipação social possa se expressar simplesmente pela política. Desde a sua ruptura com Althusser (Rancière, 2012), Rancière busca entender as condições reais por trás das 
revoluções e, assim, desloca a noção de revolução do mero campo de uma concepção ontológica da política, tal como se encontra na filosofia de Badiou. Conquanto o trabalho filosófico sobre a política de Rancière, se dirige aos arquivos pela documentação que permite a história se mostrar, como no caso da pesquisa sobre As noites do proletariado e O Mestre Ignorante, Badiou rejeitava a "filosofia política" para salientar que é a filosofia que tem tudo a aprender da política, e não o contrário. De acordo com Badiou, a relação entre política e filosofia se expressa em três níveis: como discurso que condiciona a filosofia, enquanto produtor de novas subjetividades emancipadas; por fora da política, em ações militantes que, na verdade, não precisam e não manifestam um vínculo com a filosofia; e finalmente, como participando de uma ontologia pela qual a transformação política radical adquire sua legitimidade. Este último nível marca uma primeira discordância entre Rancière e Badiou, mesmo se Badiou, possivelmente pela solidez e riqueza do trabalho de Rancière, recentemente deixa permear uma dimensão empírica e histórica na sua reflexão sobre a política, tal como no livro, Le Réveil de l'histoire.
A segunda grande diferença entre as visões sobre a política nestes autores é o conceito de igualdade, e, por conseguinte, o da ética e da democracia. Para Rancière, a igualdade é uma condição primária, um axioma de base, entre os seres humanos. Para Badiou, ao contrário, a igualdade é alcançada apenas pela transformação dos animais humanos em sujeitos que se constroem em ruptura com o Estado vigente, Estado este antiético, corrompido e profundamente desigual, seja o francês ou o brasileiro.

Para voltar ao tempo presente, podemos dizer que desde 2009 há um retorno, no contexto europeu e norteamericano, do interesse na questão do comunismo como extensão possível de uma ética filosófica que não seja apenas de jure, mas de facto. Contudo, trata-se de uma ideia do comunismo não adversa a certas teses do liberalismo, mesmo se a negociação com o liberalismo não deixa de ser antagônica.

A ética e sua variante mais recente, a ética aplicada, visa tanto à aplicação da lei quanto à justificação publicitária do comportamento social e empresarial, visto que os efeitos destes comportamentos sempre excedem o mero indivíduo, e envolvem a comunidade na sua totalidade, mesmo que indiretamente. Não obstante, a 
radicalização da ética percebida na atual reflexão sobre a ideia comunista visa condições melhores e mais eficazes para que se possa organizar, a partir da sociedade, uma contestação que forçará o Estado de direito a assumir suas responsabilidades diante da crise financeira internacional de 2008. A ideia comunista já proporcionou várias grandes reuniões na Alemanha, na Inglaterra, e, recentemente (em junho de 2012), nos Estados Unidos e a publicação de uma série de livros. Deve ser nítido que o projeto da ideia comunista procura nada menos que retornar às formas esclerosadas do comunismo que já conhecemos - ou pensamos conhecer - do Stalinismo, e ainda menos do período de (Leonid) Brejnev, em que a União Soviética exercia uma dominação industrial, militar e econômica sobre os países da Europa oriental, o antigo bloco soviético. A ideia atual evidencia a possibilidade de abertura e de reflexão crítica e criativa sobre comunismo como projeto da pesquisa ético-científica. A sua proposta é reforçar as ações dedicadas a criar um modelo substancialmente expansivo e didático das formas do capitalismo parlamentar democrático, hoje em existência, em que o esforço para esvaziar a inclusão de análises dos modos de produção parece incansável.
Neste contexto, é nítido que a questão dos Direitos Fundamentais dos indivíduos e as condições sociais do individualismo, ao qual estamos acostumados nos países ocidentais, devem ser tratadas cuidadosamente. Não existe aqui uma proposta para impor um sistema de coletivismo, no qual os indivíduos se tornam tão iguais que perdem uma liberdade que apenas a diferença pode discriminar, mesmo que ao imaginar a perpetuação da atual divisão do trabalho e a sua precarização demonstrará a falta de compreensão das raízes do problema da desigualdade. Foi a falta generalizada de direitos civis, ou a suspensão deles, que mais identifica ou associa o horror que as formas de Estado ou de organização de Estados, anteriormente denominados comunistas, desperta. Tais exemplos caracterizam certas experiências comunistas, embora certamente não todas, nem tampouco identifique apenas $\mathrm{o}$ comunismo. Talvez o comunismo esteja sendo mais cobrado devido ao seu profundo compromisso ético, ao invés de que foram as expectativas das ditaduras militares que queimaram a América latina nos anos 1970. Então se deve também admitir que nenhuma experiência de instalação de um governo comunista na história, até quando foi votado em eleições 
livres, conseguiu se desenvolver sem se confrontar a constantes ameaças de ação militar das formas mais variadas. Na nova reflexão em torno de uma política igualitária, recusa-se incondicionalmente o uso da força do Estado para eliminar vozes de oposição. Porém, seria suicídio negar o direito de autodefesa.

Portanto, na reintrodução da ideia comunista nos projetos de transformação social, constata-se um novo encontro com um conceito cuja história é muito mais rica que aquela à qual se reduzem as mídias privadas da família Murdoch, ou aqui dos Marinho e seus emissários intelectuais do Instituto Milenium. O desafio é o seguinte: como e onde aprender esta história? Como e onde encontrar condições pela reflexão e pela pesquisa sobre a ética no âmbito da ideia comunista? Durante uma geração já, é possível estudar a ética das empresas, a ética do liberalismo, a ética da responsabilidade política e profissional. É mesmo possível estudar a ética jurídica, embora com mais dificuldade em cursos de direito, pois se descobre que em muitas instâncias o terceiro poder constitucional assegura a sua independência principalmente perante os magistrados indicados pelo poder executivo, quando e se a desejavam. Da mesma forma, o desafio é de reunir uma comunidade de pensadores pesquisando não apenas um simples sonho por uma sociedade igualitária, mas as razões profundas para entender porque, em várias instâncias da história, este sonho mal se distinguia de um pesadelo. Desde 2008, porém, o momento pegou velocidade e o rei do capitalismo de mercado se mostrou nu. Uma intervenção massiva do Estado se tornou necessária para salvar os mercados dos capitais - assim contradizendo as mais primárias teses sobre a economia capitalista. Agora, os projetos de pesquisa se justificam. Alguns grupos de pesquisa estão encontrando os meios de expressão dignos da expressão "liberdade em pesquisa".

A possibilidade de ter uma vida melhor em outro contexto, em outro tempo, está passando novamente por um tempo de construção racional, que separa as potencialidades do real daquelas forças que o sonho inventa. $\mathrm{O}$ estudo da história e da filosofia, juntado à convocação da lógica, da economia, da administração e das relações internacionais, estão ampliando aquilo que deve atrair as melhores mentes. Há pensadores como Badiou, Žižek, Rancière, Löwy e Harvey, entre muitos outros, que estão mais focados na viabilidade de manutenção das novas subjetividades surgidas nas 
revoluções. Os grupos de pesquisa devem se internacionalizar para que a criação, talvez de novas instituições, possa realizar um projeto de organização política. Tudo das revoluções de 2011 está aberto a seu êxito, mesmo se a sua criação parece travada. De qualquer forma, a revolução profunda, de transformação dos modos de produção, não obedece ao desejo daqueles que buscam o poder. A sua expetativa de vida perpassa a de qualquer indivíduo.

Desta forma, espero ter mostrado, pela análise do "observatório francês" como uma parte destes projetos de pesquisa se orienta a desconstruir a questão dos Direitos Humanos no contexto da ética. A própria posição de política dentro do pensamento de Badiou insiste que a Ética deve ser uma designação apenas quando diz respeito às responsabilidades do novo sujeito que surge a partir de uma ruptura para com o Estado de situação atual. Badiou avança um sistema em que não existe um sujeito antes de um acontecimento, porque incorpora a ideia do radicalmente novo. Então, na ordem da política, o sujeito radicalmente novo terá a função de identificar o acontecimento como sendo a sua razão de "estar", ou o seu motivo de ser. O sujeito se torna mais complexo na medida em que existe uma produção de verdades na ordem da política e que este sujeito se mantem fiel a esta produção de verdades. A produção de verdades na ordem da política se confirma como certa quando a referência é o igualitarismo, tanto nos direitos quanto na economia.

Por isso, o nome de comunismo em Badiou designa a realização da noção de justiça. No recente livro, La Relation énigmatique entre la philosophie et la politique, encontramos uma reavaliação da democracia. Antes de mais nada, a democracia está vista como uma condição para o surgimento da filosofia. Na história, sabemos que a filosofia surge no contexto da Atenas, na Grécia antiga. Mas no que diz respeito às expectativas da filosofia para contribuir na criação de novas subjetividades políticas, a democracia deve funcionar como pressuposto, ao invés de finalidade, argumenta Badiou.

Sabe-se também que Platão, ao escrever no contexto da democracia ateniense, desqualificou-a como sendo uma forma de governança descontrolada, potencialmente caótica, sem uma liderança bem formada. O risco é que esta condição leva forçosamente à tirania. É uma análise que não deve ser tratada superficialmente. Platão está escrevendo no contexto da derrota de Atenas contra a cidade rival de Esparta e a Liga do Peloponeso na Guerra 
eponímia. A democracia ateniense não tinha conseguido se manter firme na sua ambição expansionista, o que desencadeou um processo de decadência da sua estrutura interna também no fim da Guerra e, particularmente, após a derrota contra Esparta. A democracia passará historicamente a uma forma de oligarquia, mesmo que volte numa forma já outra do que lidava o falecido Péricles. Foi esta democracia que condenaria Sócrates à morte. Portanto, mais uma razão para Platão questionar o carácter ético e justo desta forma de governança.

Badiou reconhece que a democracia é a forma de governança em que a filosofia nasceu. Mas a democracia não pode ser vista como a única e inquestionável forma de governança, pois a filosofia, antes de ter um compromisso com o princípio de liberdade, que a democracia defende, deve assegurar as condições para que este princípio possa ser estendido para todos. Ela deve ter um compromisso com a questão da igualdade. Então, a democracia, segundo Badiou, é uma condição da filosofia, mas a democracia não tem uma relação direta com a justiça. Ora, a justiça é o nome filosófico da verdade no campo político.

Esta posição permitirá a Badiou ousar, o que nos anos 90 justamente não se apresentava como sendo possível, ou seja, questionar de fora da democracia a viabilidade e o carácter ético desta forma de estrutura de governança. O que vem depois faz parte do programa de pesquisa, mas certamente um dos princípios que reencontramos em Rancière, segundo $\mathrm{o}$ qual a liberdade, aquela liberdade que subscreve à doutrina dos direitos fundamentais do indivíduo, deverá ser indexada à questão da igualdade. Igualdade econômica, aqui fazendo parte da criação de verdades em Badiou, e enquanto na perspectiva de Rancière, a igualdade econômica envolve a inclusão daqueles que são deixados fora da conta. Desta forma, trabalhando em termos de uma aritmética, uma contabilidade efetiva dos ganhos da democracia, esta contabilidade só pode falsificar os dados se ainda pretende que o balanço esteja realizado. Sabemos que nas ciências contábeis existe uma tendência a falsificar os números da produção de várias empresas, isso também tendo contribuído à crise financeira internacional. Quais informações foram realmente comunicadas ao público e quais informações foram reservadas para os comitês de administração e à diretoria de vários bancos? Por qual razão exatamente o Banco Lehman Brothers foi deixado ir até a falência, enquanto outros receberem 
os "bailouts" que, conforme o mesmo princípio da doutrina de neoliberalismo, nem podiam ser usados para salvar a saúde dos cidadãos? Nestas indagações, concluirei na constatação que, em pensadores como Badiou e Rancière, encontramos a dedicação para manter os critérios mais exigentes sobre o liberalismo democrático, para justamente não permitir que uma doutrina de etos se apresente como valendo para o comum e o universal.

Para completar, uma análise do contexto em que mais uma vez a democracia parece não atender a uma demanda social e pública de reforma, e algumas notas sobre a situação em Quebec. O Canadá é composto por 10 províncias, e três territórios parcialmente autônomos com governança indígena. Em cada província existe um primeiro ministro, na terminologia portuguesa e francesa (em inglês, um “premier"). No nível federal, existe o primeiro ministro federal. No Quebec, tem atualmente um processo de campanha eleitoral - pré-eleitoral, em que o governo de Jean Charest, que é o primeiro ministro há nove anos, está sendo avaliado pelo público.

Em fevereiro deste ano de 2012, depois de mais de um ano de aviso feito ao público, o governo decretou que as mensalidades e as matrículas das universidades subiriam $75 \%$ em cinco anos. No Canadá, não existe um sistema diferenciado de ensino superior, ou seja, todas as universidades são públicas e particulares. As mensalidades das universidades dependem de cada província, uma decisão que cabe aos governos provinciais.

No Quebec, as mensalidades permaneceram entre as mais baixas do país. Isso ocorreu por causa de lutas sociais históricas desde os anos 1960 e em função da importância vista pelos governos provinciais sucessivos desde aquela época para criar uma classe de profissionais nativos e francófonos. Esta classe, no Quebec, era ausente por causa da dominação britânica da economia da província. O Quebec descende da história da Nouvelle France, cuja parte no litoral do Oceano Atlântico e no vale do rio SaintLaurent, foi conquistada pelos ingleses em entre 1758 e 1763. Durante mais de um século, o regime colonial britânico tentou assimilar a população francófona. A estratégia não terminou com a criação de um Canadá federativo, composto de apenas quatro províncias em 1867. Em diferentes momentos e, particularmente, graças à Igreja católica e certas formas de governança pouco democráticas, a língua e a cultura francesa sobreviveram. 
Nos anos 1960 ocorreu o que se chama no Quebec a "revolução tranquila", o que se chama uma revolução silenciosa. Foi nesta revolução que se iniciou a reversão da situação pós-colonial, e os québécois nativos começam a tomar posse das industriais e do comércio. Antes as profissões reservadas aos québécois eram ser professor no ensino médio, trabalhar como operário nas minas ou se tornar padre. A partir do fim dos anos 60 o governo proporcionou um sistema de educação no Quebec com mensalidades baixas, com uma visão bastante concreta, a saber, permitir justamente a constituição desta classe. No momento em que entrou no poder, em 1976, o governo independentista do Partido Québécois, a lei que decretou que o francês será a única língua oficial da província, despertou uma fuga de empresas anglo-americanas, anglocanadenses e anglo-saxãs da província. Isso deixou vagas vazias num grande número de setores da administração pública, que foram sucintamente preenchidas por esta nova classe formada nas universidades québécoises.

Pulando para 2012... Em fevereiro, após vários meses de aviso pelo governo provincial, foi decretado o início do aumento das mensalidades durante $\mathrm{o}$ espaço de 5 anos. Isso despertou uma greve de estudantes universitários, em que se argumentou que, ao contrário do que acontece nas universidades dos Estados Unidos e no resto do Canadá, os estudantes québécois não queriam criar as condições de se encontrar com uma dívida enorme a pagar, preço simbólico para se formar na educação superior. Sabemos que as dívidas dos diplomados nas universidades norteamericanas somam, às vezes, acima de 10 ou até 20 mil dólares. As dívidas podem ser pagas em um longo período, mas durante os primeiros anos da vida profissional estes graduados estão obrigados a resolver este aspecto da dívida.

A própria economia do Quebec não está numa crise atualmente. Além da renda expressiva proveniente de vender eletricidade à cidade de Nova York, Quebec recebe em termos de impostos e investimento direto, dinheiro de empresas interessadas em desenvolver minas e explorar os recursos naturais da parte norte do Quebec. Por esta razão, os estudantes québécois indignados com o quadro de endividamento entraram em greve, que foi recebida com uma violência de Estado impressionante. Uma violência policial que despertou na população ainda mais apoio, chegando a passeatas envolvendo $200 \mathrm{mil}$ pessoas nas ruas de Montreal. 
Em junho, esta democracia, em resposta a uma demanda social e à oposição dos estudantes das universidades, e pela necessidade de proteger o evento da corrida da Fórmula 1, o governo decretou uma lei de exceção, interditando qualquer reunião pública nas ruas e ameaçando com prisão e multas altas qualquer membro da sociedade participante destas manifestações. Esta lei, a Lei 78, é uma lei de exceção, mas uma lei, digamos, "light", porque é uma lei que não contradiz o compromisso do Estado do governo québécois a proteger os Direitos civis e Humanos. É uma lei que não deixa em prisão por tempo longo, e não submete à violência física, à tortura, os detidos. Conseguiu, mesmo assim, colocar na prisão, por pouco tempo, mais de 2000 cidadãos, 2000 estudantes. Ao mesmo tempo, possibilitou a transformação da greve em movimento social, "greve social", que afinal exigiu do governo a chamar eleições. O governo se encontrou também num contexto em que sedefendeu de várias acusações de corrupção numa CPI instituída em junho.

Estamos agora num período préeleitoral com a lei de exceção ainda em vigor, ou seja, com todas as manifestações proibidas. Os alunos decidiram voltar às aulas, porque a lei de exceção também decretou o retorno antecipado em meados de agosto, em vez de setembro. Nao volta dos alunos às aulas, havia pouco confronto com a polícia antes do período eleitoral, assim seguindo as orientações feitas por vários intelectuais, filósofos e sociólogos para que o governo não aproveitasse da violência para ser eleito novamente. Enfim, no Quebec, encontra-se uma posição de um governo democrático não responsivo às demandas dos alunos, ao passo de encarcerar e endividá-los. Uma lei de exceção para comemorar uma eleição pas comme les autres.

No Quebec podemos, talvez depois da eleição, retornar a olhar esta situação e dizer que: "Bom, o maior movimento social do país foi absorvido e controlado por um governo que manifesta seus interesses diretos com as grandes empresas e particularmente com as grandes empresas desenvolvimentistas dos recursos naturais do norte da província." Ou poderemos ver, como em tantos outros casos atualmente, que a democracia anda de maneira cada vez mais no ritmo da aparência, conquanto o que está sendo orquestrado por trás do sistema é um reforço do poder oligárquico sobre as instituições e a economia do país.

Essa é uma especulação. O que é fato é que quando olhamos para trás, há 15 ou 20 anos, as críticas feitas aos Direitos 
Humanos por pensadores de esquerda, como Alain Badiou e Jacques Rancière, e questionamos a reação que estas críticas despertaram na sociedade, verificamos que geralmente foram tratados como autores malditos. Questionaram a bela realização das democracias liberais, a que sobreviveu à guerra fria contra os princípios totalitários do comunismo. Estamos talvez com elementos para entender melhor o que já estava em curso, o que já estava em desenvolvimento naquela época. Ajustamos nosso olhar para ver aquilo que estava atrás da faixada, no gesto de um Estado oligárquico ao se denominar democrático. O que constatamos diz respeito a outras análises da época, mais favoráveis à vitória do liberalismo, é que quando não simplesmente erravam, outros discursos justificavam a concentração e a acumulação de poder e de riqueza nas mãos de poucos por meio da celebração da ética, da democracia e dos direitos humanos.

Agradeço vocês pela atenção e podemos falar mais durante o debate.

\section{Notas}

${ }^{1}$ Fala apresentada na mesa 1 , intitulada "Sujeito de Direitos", no Evento "Temas em Debate", realizado no dia 24 de agosto de 2012 e promovido pelo curso de Doutorado do Programa de Pós-Graduação em Psicologia Social e Institucional da UFRGS. A Transcrição da gravação original foi realizada pela doutoranda Tatiana Baierle e revisada e pelo autor.

${ }^{2}$ Professor do Programa de Pós-Graduação em Filosofia da PUCRS.

E-mail: normanmadarasz@yahoo.ca

\section{Referências}

Badiou, A. (2011a). Corpos, linguagem, verdades: sobre a dialética materialista. Margem Esquerda Ensaios marxistas, 16, 111-121.

Badiou, A. (2011b). Le Réveil de l'histoire. Circonstances, 6. Paris: Nouvelles Éditions Lignes.

Badiou, A. (2011c). La Relation énigmatique entre la philosophie et la politique. Paris: Germinia.

Badiou, A. (1995). Ética - Um ensaio sobre a consciência do mal. Rio de Janeiro: Relume-Dumará. (Original publicado em 1993)

Castoriadis, C. (1989). L'idée de révolution a-t-elle encore un sens? (entretien). Le Débat, 57, 213-224.

Eribon, D. (1996). Michel Foucault e seus contemporâneos. Rio de Janeiro: 
Jorge Zahar Editor. (Original

publicado em 1994)

Gauchet, M. (2007). L'Avénement de la démocratie. Tome 1: $\quad \ll \mathrm{La}$ Révolution moderne ». Paris: Gallimard.

Gauchet, M. (1998). La religion dans la démocratie - Parcours de la laïcité. Paris: Gallimard/Folio.

Madarasz, N. (2012). On s'en câlisse de la Loi Spéciale 78: Da greve estudantil à "greve social" na Primavera Québecoise. Margem Esquerda Ensaios marxistas, 19.

Rancière, J. (2012). La Méthode de l'égalité. Entretiens avec Laurent Jeanpierre et Dork Zabunyan. Paris: Bayard.

Rancière, J. (1996). O Desentendimento Política e filosofia. São Paulo: Editora 34. (Original publicado em 1995). 